\title{
FGFR3 Gene Alteration Positive
}

National Cancer Institute

\section{Source}

National Cancer Institute. FGFR3 Gene Alteration Positive. NCI Thesaurus. Code C150618.

An indication that mutation, overexpression, fusion or rearrang ement involving the FGFR3 gene has been detected in a sample. 